\title{
Language shift or maintenance? Factors determining the use of Afrikaans among some township youth in South Africa
}

\author{
Charlyn Dyers \\ University of the Western Cape, Private Bag X17, Bellville 7535, South Africa \\ cdyers@uwc.ac.za
}

\section{Introduction}

The aims of this paper are as follows:

- to investigate how high school learners in a township school in South Africa report on their use of, and attitudes toward, their first language, Afrikaans; and

- to use the findings to show how, given their particular situation, the language continues to be strongly maintained in this community, and remains an important index of both their group and individual identity.

Much has already been written about the dominant role of English in South Africa today (cf., e.g., Ridge 2000, 2004; Webb 2002; Alexander 2004), and the perception that there is a largescale shift towards the use of English at the expense of other mother-tongues and home languages (cf. De Klerk 2000; Kamwangamalu 2003). This large-scale shift, however, may either not be taking place or be taking place at a much slower rate in many communities of practice in South Africa. It is the contention of this paper that this shift is far more marked in middle-class and upwardly mobile black and mixed-race families in South Africa, and that various factors work against this shift in working class and rural communities. Some of these 
factors include (i) the environment in which these people live, (ii) a desperately burdened and poorly-functioning state education system in poorer rural and urban areas (Soudien 2007; Taylor 2007), (iii) historically low levels of literacy, and (iv) relatively low mobility for the poor and working class in post-democratic South Africa.

At the same time, one also needs to take account of the factors that support the maintenance of home languages and mother tongues in South Africa. Central to these maintenance factors must surely be the role of language in defining people's ethno-cultural identities, in an era where belief in a common South African identity is still a vague dream, and ethnic/tribal identities have re-emerged as a central anchoring point for many groups like the Afrikaners, Xhosas and Zulus. The focus of the present work is on a particular working-class township where $75 \%$ of the population are members of the most diverse ethnic group in South Africa, the mixed-race "Coloureds". ${ }^{1}$ A number of sociolinguistic studies have been carried out in this township, namely Wesbank, which forms part of Greater Cape Town in South Africa. These studies have looked at the language attitudes of high school learners (Dyers 2004), the peripheral normativity in the literacy skills of such learners (Blommaert, Muyllaert, Huysmans and Dyers 2005), and the degree of multilingualism among some of these learners (Dyers 2008). The interest in the township stems from its position as one of the first racially integrated housing developments in post-democratic South Africa.

This paper continues the longitudinal exploration reflected by the above studies of how "Coloured" South African high school children in Wesbank negotiate their individual and collective identities through language. The longitudinal study aims to find out how high school children from diverse backgrounds and marginalised by poverty, location and race reflect a sense of individual, collective and national identity through language.

\section{Background}

There can be little argument against Appel and Muysken's (1990:23) contention that "the identity imposed by one's group membership is a crucial factor for language choice". The population of South Africa is made up of many diverse groups speaking different languages, and the diversity of identities was engineered to be regarded as even more separate and distinct both by 300 years of colonialism and by the apartheid regime of more than 40 years 
(1948-1994), whereby there was separate development for all races under white rule. As a language, Afrikaans has suffered historically because of its association with the 40-odd years of apartheid. It was the language of the rulers of this period, the Afrikaners, and became known during the years of struggle against this system as "the language of the oppressor".

At the same time, however, Afrikaans is the mother tongue of the majority of the group which was classified as "Cape Coloured" during the apartheid era in South Africa. The majority of this group reside in the Western Cape Province of South Africa, where 55\% of the population speak Afrikaans as mother tongue, followed by 23\% whose mother tongue is Xhosa and 19\% whose mother tongue is English (South African Population Census 2001). The group also displays varying degrees of bilingualism in Afrikaans and English (from "mainly English" in some suburbs to "mainly Afrikaans" in others), as well as multilingualism in Afrikaans, English and Xhosa, depending on their levels of literacy, education and location. Other languages that play smaller roles within this group are Arabic (particularly in the Muslim community) and German (which was a popular school subject in the previous dispensation). However, despite the close identification of many members of this community with Afrikaans, there are also signs of a shift towards English, particularly among middle-class "Coloured" families (Malan 1996; Anthonissen and George 2003; Warner 2008). The children in these families are educated in English, and despite strong exposure to Afrikaans in the family and community environment, tend to use only English in conversation with others.

It is indisputable that the "Coloured" population of South Africa participated in the development of Afrikaans out of the Dutch spoken by the first European colonists, who arrived in South Africa in 1652. Many of the "Cape Coloureds" are descendants of South Africa's earliest inhabitants, the San and the Khoe, as well as unions of members of these tribes with the European settlers and people from Asia and other parts of Africa who were brought to South Africa as political prisoners and slaves by the Dutch, French and English colonists. Cape Dutch (later Afrikaans) developed out of the need for these extremely diverse linguistic and ethnic groups to communicate (Malan 1996: 127).

Language plays an important role in defining who we are, and makes us instantly recognisable to other members of our particular speech community. As Joseph (2006: 39) puts it, "we read the identity of people with whom we come into contact based on very subtle features of 
behaviour, among which those of language are particularly central". Despite the shift to English in the middle class families reported above, most "Coloured" people in the Western Cape continue to speak Afrikaans as their mother tongue, and the language remains a key component of their ethnolinguistic identity (Titus 2008). The sociopolitical history of South Africa has led to the "Coloureds" developing as a group with a particular identity which sets them apart from white Afrikaners who share their language (Stone 1995: 277-281). Unlike the latter group, they have never displayed the same "emotional investment in keeping the language pure" (McCormick 1989: 206). But the majority identify closely with the vernacular variety of Afrikaans which they use every day, regarded by McCormick (2000), Malan (1996) and others as a mixed code, which incorporates many English loanwords. During a focus group interview carried out in the third year of the longitudinal study of Wesbank teenagers, one girl had the following to say about the variety of Afrikaans spoken in the township:

(1) Os praatie yntlik regte Afrikaans nie. Os praat Kaapse Afrikaans, Engels en Afrikaans deu'mekaar.

(We don't actually speak proper Afrikaans. We speak Cape Afrikaans, a mixture of English and Afrikaans.)

For this informant, her variety of Afrikaans was not proper, standard Afrikaans, but an informal mixture of Afrikaans and English. According to Hendricks (personal communication, 2006), it would be more accurate to use the term "Kaaps" (reportedly first used by the writer Peter Snyders) for this variety instead of the more commonly used "Cape Flats Afrikaans", as there are variants within this variety. These variants will display either more or less code-mixing with English as one travels from the centre of Cape Town to its suburbs, peripheral townships and surrounding rural areas. The two extracts from the focus group interviews in year three of the study in (2) and (3) are typical examples of the spontaneous, unmarked conversational code-mixing prevalent in Wesbank. (Code switches are marked by the use of italic script for English and regular script for Afrikaans.)

(2) S1: Well... met my ma is ek meer relaxing, like ek en my ma praat, ek sal my ma alles vertel.

(Well...I'm more relaxed with my mother. When my mother and I chat, I will tell her everything.) 
(3) S2: Ja... maar my ouma wat nou oorlede is... Ek en sy was eintlik close aanmekaar. (Yes... but my grandmother who died recently... She and I were actually close to each other.)

The linguistic convergence of English and Afrikaans in Cape Town and other parts of South Africa is visible in the local varieties of both languages (McCormick 1995: 203). In addition, location, education and role models all have a role to play in the varieties of vernacular Afrikaans spoken by "Coloured" people all around South Africa, and there are a number of studies of these different varieties (e.g. Combrinck 1978; Webb 1989; Roberge 1995; Hendricks 1996).

Further evidence of the close identification with Kaaps is provided by the strong attachment of many "Coloureds" to the works of poet and playwright, Adam Small, who writes in vernacular "Cape Flats" Afrikaans, the immense popularity of the music of rap and hip-hop artists who use it (e.g. Brasse vannie Kaap, Prophets of Da City), and the success of theatrical productions using the vernacular, like Joe Barber (Petersen, Isaacs and Reisenhöfer 1999) and Suip! (Petersen and Reisenhöfer 1999). As Stone (1995: 280) puts it, "the dialect is beloved by its speakers as the sacramental marker of communal membership and a vehicle of intimacy and love". While its speakers acknowledge its low status in relation to standard Afrikaans, ${ }^{2}$ it is fair to say that it enjoys a certain status as well as strong vitality in the poor, working-class townships of the Cape Flats. This is a large area on the periphery of Cape Town, which includes Wesbank Township, to which the "Coloured" population of Cape Town was forcibly moved at the height of the apartheid regime.

Wesbank Township, which has only been occupied since 1999, is by all accounts a peripheral township marked by poverty, unemployment and crime (Dyers 2004). The current demographics of the area (Havenga 2006) show that, of a total population of approximately 29000 people, approximately 73\% are mixed-race, mainly Afrikaans-speaking "Coloured" people and $25 \%$ are Xhosa people, many of whom have recently migrated to the Western Cape Province of South Africa from the Eastern Cape Province, where this ethnic group constitutes the majority population. A further $2 \%$ are White, Asian or foreigners from other parts of Africa like Somalia, Nigeria and The Congo. The township consists of small housing units, a high school, three primary schools and a supermarket. There are no public amenities 
such as a community centre, parks or sports fields and those who work mainly travel to the more prosperous suburbs of Cape Town by minibus taxi, which is the most common and cheapest form of public transport.

The question therefore arises: How does this new space organise people and their patterns of language use? The issue of space and multilingualism has been investigated extensively by Blommaert, Collins and Slembrouck (2005), whose overarching interest is in how "people are positioned and [in] the communicative potential they display and have attributed to them in diverse, scale-sensitive situations and practices" (Blommaert, Muyllaert, Huysmans and Dyers 2005: 210). Their research has led them to conclude that multilingualism is not what people have, or do not have, but what their environment enables or disables them to use. As the study by Blommaert, Muyllaert, Huysmans and Dyers (2005) has shown, such enabling and disabling environmental forces are also present in Wesbank.

\section{Terms of reference}

One of the most common definitions of language shift is that it takes place when the younger members of a minority speech community no longer speak the language of their parents, but speak a dominant majority language instead. The language of the parents is therefore not passed on to the next generation. Conversely, language maintenance occurs when a language continues to be used across all generations despite the presence of other languages also being used by a community - the kind of stable diglossia defined by Fishman (1972). According to Myers-Scotton (2006: 89), two generalisations may be drawn from all studies on language shift and maintenance, namely -

- There is "always a combination of factors at work" supporting either shift or maintenance; and

- In a bilingual community, patterns of maintenance and shift can be measured on a continuum with some individuals using only the first language (L1) at one end of the continuum and others using only the second language (L2) at the other end. In intergenerational shift, for example, we might find the older members of a family using the L1 (but having some competence in the L2), while the children, despite 
having almost perfect comprehension of the L1, speak only the L2 (cf. also Warner 2008).

In addition, Myers-Scotton (2006: 90) lists the following societal, in-group and individual factors as being among those factors central to language maintenance:

- demographic factors - large numbers of speakers of the same L1 living together;

- occupational factors - working with fellow speakers of the L1, with restrictive socioeconomic mobility;

- educational factors - e.g. official provision of the L1 as a medium of instruction;

- social networks and group attitudes about the L1 as an ethnic symbol; and

- psychological attachment to the L1 for self-identity.

The above factors are certainly present in the predominantly Afrikaans-speaking "Coloured" community of practice living in Wesbank. I use the term "community of practice" here to distinguish it from the wider concept of 'speech community' and to show that differences in language practices exist in different "Coloured" communities. For Lanza (2007) this concept captures the reality that even smaller groups can have their own ways of speaking, acting and believing. Although the "Coloured" inhabitants of Wesbank may have migrated to the city from various urban and rural communities, most members of this community of practice experience no difficulty in communicating in Afrikaans with one another. Their children attend the township schools, where Afrikaans is taught as L1 and is one of the official media of instruction (the other being English, principally to support large numbers of Xhosa learners also attending these schools). In most of the churches in the township, Afrikaans also plays a leading role, although a switch to English may occur when non-Afrikaans speakers are present in the congregation. Poverty, unemployment and low levels of literacy further restrict the socio-economic mobility of this working-class community. As a particular space organising people's linguistic choices, the township therefore appears to play an enabling role in the maintenance of Afrikaans. Historically, too, Afrikaans has always played a significant role in the group identity of the "Cape Coloured", constructed as this identity might be for some. It is perhaps the main marker of a "Cape Coloured" identity, particularly in the absence of a clear group culture and identity (Dyers 2004: 31), given the huge diversity of origin in this group. This possibility was borne out by the data on attitudes towards Afrikaans collected 
for the present study, which revealed a psychological attachment to the language for selfidentity as well as group identity.

Thim-Mabrey's (2003) distinction (cited in Schmidt 2006:15) between linguistic identity on the one hand and identity through language on the other is of relevance here. Linguistic identity means the features of a given language which distinguishes it from other languages, but also the identity of a person with regard to his/her - or in fact any - language. Identity through language, on the other hand, describes "the identity of persons insofar as it is constituted or co-constituted through language and language use".

However, the combination of factors supporting either shift or maintenance may also influence individual language choices. An individual may be part of a community of practice where one language is strongly maintained, but may for personal and subjective reasons reveal different patterns of language use and attitude to those of the dominant group. In other words, individual identity in terms of language could in some circumstances differ from group linguistic identity. As Tabouret-Keller (1998) contends (cited in Mills 2005), identity is both a social construct, characterised by objective features (such as language), and a personal, subjective construct, characterised by individual mental processes and choices. Individual choices in terms of language can therefore be far more varied than those of the group to whom the individual belongs, depending on his/her particular circumstances and environment. An individual's linguistic choices can -

- reflect almost exactly those of the group to which the individual belongs;

- show degrees of overlap, but with varying degrees of difference, e.g. sounding more/less accurate than the source group or exhibiting greater use of code-switching and experimentation with the language; or

- reveal varying degrees of rejection of his/her group's dominant language/s - this could include increased borrowing of terms from a preferred language, adopting a way of speech that makes the individual sound different to the rest of the source group, e.g., more/less polished, or refusing to speak the language despite having grown up with it, like the middle-class "Coloured" children in Warner's (2008) study. 
In the Wesbank survey, most of the individual linguistic choices of the respondents fitted into either the first or the second category listed above. There were also individuals who were multilingual in Afrikaans, English and Xhosa as a result of growing up in multilingual families which use all three languages (Dyers 2008). However, even in these multilingual families, Afrikaans played a dominant role in their intimate domains. On the whole it is probably fair to say that, with the majority of the respondents, there were only finely-nuanced shades of difference between group and individual identity through Afrikaans.

Among the "Coloured" learners at Wesbank High, there were a few exceptions to the Afrikaans-dominant group. We identified a small percentage (2\%) of "Coloured" learners who defined themselves as English, rather than Afrikaans-speaking. They were in the school's English medium classes which were attended by a majority of Xhosa-speaking learners. On closer inspection, we found that while a small number were recent arrivals from other parts of the country, like Johannesburg, the rest lived in the middle-class suburb of Highbury, not far from Wesbank. This tended to confirm our perception that English, as an instrument of sociospatial mobility (cf. Blommaert, Muyllaert, Huysmans and Dyers 2005), was largely associated in the minds of our respondents with the more up-market spaces outside the confines of Wesbank. The case study of John in section 5 bears out this association.

\section{Methodology}

I began my longitudinal research at Wesbank High School in 2004 with the assistance of student research assistants, electing to work with high school learners for two reasons, namely -

- as one type of language shift occurs when young members of a community no longer speak their parents' L1, these learners would be able to provide evidence of such a trend; and

- high school learners would be better equipped than primary school learners to articulate viewpoints on often-subjective language issues.

This paper is based on data collected from Afrikaans L1 learners in Grades 8 to 10 in the first three years of our research (2004-6) at Wesbank High School. The data consist of classroom responses to a questionnaire on their use of Afrikaans in different domains (see table 1), 
written responses on the importance of the language in their lives, focus group and individual interviews, as well as informal playground observation. The classroom and written responses, as well as some individual interviews, were collected in the first two years. The respondents were 70 Grade 8 (first year of high school) and 34 Grade 9 learners. In the third year, the focus shifted to individual and focus group interviews with 12 selected Grade 10 learners, as well as informal playground observations and conversations.

\begin{tabular}{|c|c|c|c|c|c|c|c|c|}
\hline \multirow{2}{*}{$\begin{array}{l}\text { Domains of use } \\
N=70(2004) \\
N=37(2005)\end{array}$} & \multicolumn{2}{|c|}{$\begin{array}{l}\text { Afrikaans only } \\
*_{\text {with classmates }}\end{array}$} & \multicolumn{2}{|c|}{ English only } & \multicolumn{2}{|c|}{$\begin{array}{c}\text { English and } \\
\text { Afrikaans } \\
* * \text { with teachers }\end{array}$} & \multicolumn{2}{|c|}{$\begin{array}{c}\text { English, Xhosa and } \\
\text { Afrikaans }\end{array}$} \\
\hline & Gr 8 & Gr 9 & Gr 8 & Gr 9 & Gr 8 & Gr 9 & Gr 8 & Gr 9 \\
\hline Home & $80 \%$ & $16 \%$ & 0 & 0 & $14 \%$ & $84 \%$ & $3 \%$ & 0 \\
\hline Church/Mosque & $37 \%$ & $41 \%$ & $9 \%$ & $5 \%$ & $20 \%$ & $54 \%$ & $9 \%$ & 0 \\
\hline School (in class) & $100 \% *$ & $5 \%$ & 0 & 0 & $69 \% * *$ & $95 \%$ & & \\
\hline School (playground & $80 \%$ & $70 \%$ & 0 & 0 & $17 \%$ & $24 \%$ & $3 \%$ & $5 \%$ \\
\hline Shopping (Bellville area) & $80 \%$ & $38 \%$ & $6 \%$ & $5 \%$ & $6 \%$ & $57 \%$ & $3 \%$ & 0 \\
\hline Streets of Wesbank & $80 \%$ & $68 \%$ & 0 & 0 & $17 \%$ & $32 \%$ & $3 \%$ & 0 \\
\hline With friends & $88 \%$ & $62 \%$ & 0 & 0 & $9 \%$ & $38 \%$ & $3 \%$ & 0 \\
\hline
\end{tabular}

Table 1. Domains of use over two years (2004-2005) for Grade 8 and 9 learners

\section{Findings and analysis}

\subsection{Reported language use in different domains}

I begin here with the analysis of language use in different domains, as reported by the Grade 8 and 9 Afrikaans L1 learners. Domains of language use are certain institutional contexts in which one language or language variety is more likely to be considered appropriate than another. Fishman $(1965,1968,1971)$ did some of the principal research into domains of language use, and was mainly concerned with the question: who speaks what language to whom and when? Domains are taken to be constellations of factors such as location, topic and participants, and include the domains of work, family, school and other educational institutions, circle of friends and wider communication. As situations change, so do the choices of language, variety and register. A key influence in both formal and informal domains is the relationship between the interlocutors (Dyers 2008). Our examination of the 
reported language use in different domains revealed a number of similarities between the Grade 8 and 9 data, as well as some interesting differences as the young people responded actively and creatively to their multilingual environment. Afrikaans was the dominant, but not the only, language used on the school playground, the streets of Wesbank, and with friends. English was rarely used on its own, and very few of these learners used a combination of Afrikaans, Xhosa and English. English was mainly encountered at school, where some teaching was done through English only, especially when these learners were taught certain subjects together with their Xhosa peers. ${ }^{3}$

Percentage-wise, far more Grade 9 than Grade 8 learners reported the use of both English and Afrikaans at home. However, it appears that, in the home environment, learners from Afrikaans-dominant homes viewed intra-sentential code-mixing of Afrikaans and English as "speaking English" (Dyers 2008), as is reflected by the utterance in (4). In addition, some families often addressed the youngest children in English, but spoke to one another in Afrikaans. The Grade 9 respondents also appeared to be using both languages much more than the Grade 8 learners when shopping, on the streets of Wesbank and with friends. This could indicate that, at Grade 9 level, much more interaction is taking place with people who do not speak Afrikaans only, such as the Xhosa population of Wesbank, as well as people from other parts of Africa.

(4) My teacher het vir my gesê om my English homework te doen voor ek Generations kyk oppie $T V$

(My teacher told me to do my English homework before I watch Generations [a popular soap opera] on TV.)

\subsection{Language Attitudes}

The Grade 8 and 9 learners also wrote short pieces on the importance of the main languages in their lives. The written work, as well as comments made during the interviews and informal playground conversations, gave us further evidence of their prevailing language attitudes. People's language attitudes define the ways in which they rank the different languages in their repertoire, how they feel about those languages, and how they behave towards those languages and speakers of those languages (Triandis 1971: 8; Baker 1992; Fasold 1995: 148). 
A number of key distinctions can be made about language attitudes (cf. Dyers 2001), such as the following:

- Some attitudes have affective roots while others have more rational roots. Thus there are sentimental attitudes towards a language, rooted in its symbolism for particular groups, and the more instrumental attitudes, where language becomes a means of achieving certain goals, either of an economic or an educational nature.

- Attitudes are different for languages and people. It is possible to have a positive attitude towards a language while holding negative attitudes towards speakers of that language.

- Patterns of language use often contradict language attitudes. The positive regard for English among many South Africans is not matched by proficiency in use, and the relationship between attitudes and behaviour may be less causal than at first presumed.

Evidence of these distinctions can be found in the writing of the Wesbank learners. The Grade 8 learners agreed that English was important for finding work, but were sentimental, and even passionate about their mother tongue, Afrikaans. They wrote about how nice it was to speak the language, how beautiful it was and how easy it was for them to understand. Their comments thus fell either in the affective (Afrikaans) or rational (English and Afrikaans) categories. The Grade 9 written responses, however, revealed finer shades of individual identity. Although not one of these learners showed an intimate, integrative connection to English, the majority of the class ranked English higher than Afrikaans (and used the term "English" instead of the more correct "Engels" in their Afrikaans sentences). They saw the language as the key to better employment, life outside the township, communication with non-speakers of Afrikaans, and generally to a successful life. The learners also had more to say about English (either positive or negative) than the other two languages - which is also an indication of there being more things that they could say about its value in their lives. It is fair to say that these learners' patterns of language use contradicted the positive instrumental attitudes they had towards English. In addition, some held negative attitudes towards speakers of English (whom they regarded as snobbish), despite their positive attitude towards the language. 
The comments on Afrikaans came from a more personal and sentimental perspective, as is reflected by the categories of responses in (5) to (8).

(5) As the language they identified with, were raised in and which is an integral part of their group identity:

Ek kies Afrikaans want ek is groot geword met Afrikaans. My ma, pa en helle familie praat Afrikaans. Dis bilankerik want meestal mense praat Afrikaans in ons skool.

(I choose Afrikaans because I was raised in it. My mother, father and whole family speak Afrikaans. It is important because most people at our school speak Afrikaans.)

Afrikaans moet in Suid-Afrika bly van dit is deel van wie ons is.

(Afrikaans must stay in South Africa, because it is part of who we are.)

Afrikaans van die Kleurling verstaan nie die ander taal nie.

(Coloured people don't understand any other language.)

(6) As the language they found the easiest to use:

Want meeste van die mense praat Afrikaans en sekere van die mense wil vir Hulle mooi Hou oor die taal wat Hulle praat.

(Because most of the people speak Afrikaans and some of the people want to ? keep the language they speak pure.)

Ek kies Afrikaans omdat dit my eerste Taal is.

(I choose Afrikaans because it is my first language.)

Die wat nie geleerd is nie praat Afrikaans.

(Those who are uneducated speak Afrikaans.) 
(7) As a language of power in the Western Cape Province:

Afrikaanse taal baie belangrik vir die mens wat Afrikaans Praat want alles doen 'n mens in afrikaans.

(The Afrikaans language is very important for the person who speaks Afrikaans, because s/he does everything in Afrikaans.)

Afrikaans kan tweede kom want die meerderheid van die mense in die Westelike Provinsie praat dit.

(Afrikaans comes second to English and is spoken by the majority of the people in the Western Province.)

(Afrikaans) want dit is baie belangrik vir my om gou 'n werk te kan kry en baie van die mense kan Afrikaans praat.

(Afrikaans, because it is very important for me to find work quickly, and many people can speak Afrikaans.)

We note that these comments refer mainly to the role of Afrikaans as an index of their group and ethnic identity, and, to a lesser degree, to its continuing power in the Western Cape. But the contradiction between positive attitudes and actual language proficiency was also present in their written responses to Afrikaans, which revealed sharp contrasts in terms of the learners' standards of literacy or command of standard Afrikaans. While at least a third could communicate effectively in fairly clear, coherent Afrikaans, many struggled with spelling and punctuation. They wrote exactly as they spoke, in their colloquial variant of Afrikaans, often with barely legible handwriting. The two examples in (9) and (10) are taken from their comments on English.

(9) Engels is ook 'n belangrike taal van mens soos die Xhosa en die Kleurling verstaan Engels baie goed.

[Standard Afrikaans: Engels is ook 'n belangrike taal want mense soos die Xhosas en Kleurlinge verstaan dit baie goed.]

(English is also an important language because people like the Xhosas and Coloureds understand it very well.) 
(10) Ek dink English is vir ons die belangerikse want as jy eendag vir iets wil leer Dan moet jy English en ook Afrikaans ken want as jy nie english kan prat nie Dan moet jy Xhosa kan praat...

[Standard Afrikaans: Ek dink Engels is vir ons die belangrikste, want as jy eendag verder wil leer, moet jy Engels en Afrikaans goed ken. As jy nie Engels kan praat nie, moet jy Xhosa kan praat...]

(I think English is the most important for us, because if you want to study further one day, you must be good at English and Afrikaans. If you can't speak English, you should be able to speak Xhosa...)

The learners' poor literacy skills even in their mother tongue can be ascribed not only to a history of poor education, but also to the disabling influence of the environment of Wesbank, where $14.4 \%$ of the population has had no education, and the majority (45\%) only received education up to a primary school level (Moola 2002: 13).

\subsection{Afrikaans as an index of group and individual identity in the respondents}

As the excerpt in (11) from a focus group interview in year three of the study shows, the teenage respondents revealed a reluctance to say that they were from Wesbank. Their strongest allegiances were to the places from which they had originally come, and they did not yet feel that they had a particular "Wesbank identity".

(11) I: Wat sal jy sê, waar kom jy vandaan? Suzy, sal jy begin vir my?

(What would you say, where do you come from? Suzy, will you begin for me?)

S: Ek sal sê ek kom van Sutherland af, want ek is daar gebore.

(I would say I come from Sutherland, because I was born there.)

I: Sutherland, OK. Jy sê nie jy's van Wesbank af nie?

(Sutherland, OK. You don't say you are from Wesbank?

S: hmm-mm (Negative)

I: Jy voel nie of jy van Wesbank is nie?

(You don't feel you are from Wesbank?)

S: [shy laugh] Ek voel nie ek is van Wesbank af, want ek is meer gelukkig om te sê -

(I don't feel that I am from Wesbank, because I am happier to say - )

I: Jy's meer trots op Sutherland? 
(You are prouder of Sutherland?)

S: mm (Affirmative)

I: Interessant. Mona, waar sal jy sê kom jy vandaan?

(Interesting. Mona, where would you say you come from?)

M: Ek sal sê ek kom van Kraaifontein.

(I would say I come from Kraaifontein).

I: Ja, daar's baie mense van Kraaifontein wat hierso in Wesbank bly, ne? Het jy nog baie familie daar, Mona, in Kraafontein?

(Yes, there's lots of people from Kraaifontein living here in Wesbank, hey? Do you have lots of family there, Mona, in Kraaifontein?)

M: mm (Affirmative)

The first respondent (S) still identifies strongly with her place of birth, namely the rural, predominantly Afrikaans-speaking town of Sutherland. While the second respondent (M) originally came from a town quite close to Wesbank, namely Kraaifontein, she prefers to say that she comes from there rather than from Wesbank, and that she still has strong family ties with Kraaifontein. This pattern was repeated with virtually all of the respondents, who all hoped to move out of the township eventually. When the space one is forced to live in does not enhance your sense of personal identity, you instinctively look for other, more positive markers of identity. One of these is likely to be your mother tongue - in the case of these teenagers, Afrikaans.

The value of Afrikaans as an important component of their identity can be seen in another extract from the same focus group interview, given in (12).

(12) I: Nou wat is die belangrike taal vir jou?

(Now, what is the important language for you?)

E: My - my huistaal is vir my belangrik. Is Afrikaans. Meeste vannie tye, met meeste vannie mense wat ek ontmoet, praat ek Afrikaans.

(My home language is important for me. It's Afrikaans. Most of the time, and with most people I meet, I speak Afrikaans).

I: Baie interessante antwoord. Mona?

(Very interesting answer. Mona?) 
M: My moedertaal is Afrikaans, en ek was gebore daarmee. En ek sal meer Afrikaans praat as anner taal.

(My mother tongue is Afrikaans, and I was born with it. And I shall speak more Afrikaans than any other language).

I: Suzy?

S: Ek sal sê Engels en Afrikaans, want by my huis, waar ons nou Afrikaans praat, maar tussenin onse familie is Engelse mense, so ek sal Engels en Afrikaans gebruik.

(I would say English and Afrikaans, because at my home, where we mainly speak Afrikaans, there are also English relatives, so I would use English and Afrikaans).

We note here that Afrikaans is referred to as "my home language", "my mother tongue", "the language I was born with" and the language spoken "most of the time", unless Englishspeaking relatives are present. For these teenagers, the language still has considerable vitality in their new space, which enables them to use Afrikaans, and to some degree, English.

The teenagers' use of and attitudes towards the three main languages of the Western Cape revealed the dominant role of Afrikaans as an index of their individual as well as collective identities. The narrative in (13) is based on one of the individual interviews conducted during year three of the study.

(13) John is 15 and in Gr 10 at Wesbank High. His Afrikaans-speaking family moved to Wesbank from Eerste Rivier, another large township close by, when the bank foreclosed on the mortgage. His father completed Grade 11 of high school, and speaks good English. He assists John with his homework. His mother completed Grade 6, and was the one who decided that everyone in the family would speak Afrikaans. Because of the family's poverty, his one sister is being raised by his maternal grandmother. He expresses no love for English (Ek voellie om Engels te praatie), and regards himself as an "Afrikaanse Kaapenaar". Although he has English speaking cousins on his father's side, these cousins do not visit John's family, whom they regard as "too poor". His mother originally came from Tulbagh, a predominantly Afrikaans rural town in the Western Cape. He visits his maternal grandmother and the rest of his mother's family in Atlantis, a large West coast town created to house Coloured workers in the previous dispensation. He regards the Afrikaans spoken in Wesbank as being inferior to his 
own Afrikaans. He has a few Xhosa mother tongue friends, and is keen to learn the language. When he and his Xhosa friends are together, they speak a mixture of Afrikaans and Xhosa. He does not go to church, despite his mother's efforts. The church his mother attends uses Afrikaans and (very occasionally) English. He admits to struggling in English, and ranks it below Afrikaans and Xhosa.

In John's family, Afrikaans is the dominant language, but he regards the variety mainly spoken in Wesbank as being inferior to that spoken by his own family. Clearly, he is influenced by the "purer" versions of Afrikaans spoken in the rural areas where so many of his relatives live. Interestingly, John ranks Xhosa higher than English, a language which he clearly resents. He finds English difficult (he is repeating Grade 10 because of his problems with learning the language). His wealthier cousins, who are English-speaking, appear to look down on his family, which contributes to his negative attitude towards English. But he has apparently picked up some Xhosa from his Xhosa peers in Wesbank, and is keen to learn the language because of his relationship with these friends.

The level of integration in Wesbank, particularly among the young, as can be seen in John's example, is to some extent creating an enabling environment for increasing or so-called "truncated" multilingualism among the young (Dyers 2008). In an ideal world, most young people would be highly competent in their first language, reasonably competent in their second language and even show some skill in a third language (Van der Rheede, personal communication, 2006). ${ }^{4}$ However, it is clear that this multilingual competence is limited in most cases to varying degrees of verbal competence. The required competence in the standard language/s is lacking, particularly in the skills of reading and writing. The continued economic, social and spatial marginalisation of the poor in South Africa, who remain far behind the rest of the population in terms of their educational opportunities and subsequent literacy levels, is a factor that contributes strongly to the impoverishment of their education and prospects of securing good employment.

The lack of allegiance to a new common space would definitely influence people's language practices, and potentially lead to a hardening of ethnolinguistic distinctiveness as people responded to perceived threats to their group identities. Edwards' (1995: 134) reference to "a beleaguered collectivity" reminds one strongly of the current taalstryd ("language battle") of 
some of the White Afrikaners in South Africa, specifically around the inroads English is making into areas like higher education and business. But the Afrikaans-speaking Wesbank community, who have all been placed here not out of choice, but because of poverty, do not as yet reveal similar tensions around language issues, possibly owing to their numerical supremacy over their Xhosa neighbours. Instead, there is more a sense of not really belonging to Wesbank, which leads to closer identification with other markers of identity.

\section{Conclusions}

The findings of this study may indicate that there are a number of factors supporting the maintenance of Afrikaans in Wesbank. The three main factors include (i) the dominant role of Afrikaans, the L1 of the majority, in key domains of language use in the township, (ii) a powerful sentimental attachment to the language as a badge of individual and group identity, and (iii) the socio-spatial marginalisation of the community. A less central, but still important factor, is the powerful role of Afrikaans in particular sectors of the economy of the Western Cape, especially the agricultural sector, a major employer of less skilled workers. However, we note that the instrumental value of English continues to increase as the respondents surveyed here progress through high school, although many admit to struggling with this language. English has considerable power as an index of socio-spatial mobility to the world outside the township, but as long as poverty and inequality continue to trap these young people in the townships, simply learning to master English will not be enough to improve their lives, and Afrikaans will continue to be used as the main township language. At the same time, the learners' inability to perform well in both languages at school also contributes to their overall academic impoverishment.

What generalisations can be drawn from the above research? Firstly, even in the presence of a powerful language of wider communication, people can continue to identify powerfully with their home languages, especially when it enhances their personal and group identities or is a marker of their ethnolinguistic distinctiveness. Secondly, even when a particular variety has a perceived low status, it remains a powerful index of micro-networks, in-group identity and the possible exclusion of those who do not speak this variety. And finally, the choice of language or language variety in intimate domains explains in part why home languages continue to remain vital despite the use of more high status languages in other domains. Taken together 
with factors like space, poverty and social class, these factors all appear to favour language maintenance rather than shift to a more powerful language of wider communication.

\section{Acknowledgements}

The Wesbank research was made possible with the financial assistance of the Culture, Language and Identity Project of the Faculty of Arts at the University of the Western Cape. I would also like to acknowledge the valuable assistance of my research assistants, as well as the principal, teachers and learners of Wesbank High School.

\section{Notes}

1. The terms "Cape Coloured" and "Coloured" remain problematic because they are fundamentally pejorative. On the other hand they are firmly entrenched term. In this article inverted commas and a capital letter are used to indicate the dilemma of researchers. In the interests of consistency capital letters are used for Black and White as well.

2. Prof Frank Hendricks, of the Dept. Afrikaans and Nederlands at the University of the Western Cape, points out that so-called "Standard Afrikaans" has three main varieties: super-standard Afrikaans, an idealised "high" form; formal standard Afrikaans used in formal situations like lectures; and informal standard Afrikaans for more everyday use. For more information on these varieties, see Carstens (2003).

3. Wesbank High, where our research took place, is a dual medium (Afrikaans and English) school. This means that learners are either placed in the English medium classes or in the Afrikaans medium classes, but staff shortages have meant that teachers frequently have to teach both groups in one class. The Xhosa students are normally placed in the English medium classes.

4. I am indebted to Christo van der Rheede, the director of the Stigting Bemagtiging deur Afrikaans (Foundation for Empowerment through Afrikaans) and former school principal of Wesbank High, for his comments on drafts of this article.

\section{References}

Alexander, N. 2004. The politics of language planning in post-apartheid South Africa. Language Problems and Language Planning 28(2): 113-130. 
Anthonissen, C. and E. George. 2003. Family languages: Bilingualism and language shift. Paper presented at the $21^{\text {st }}$ World Congress of the World Federation of Modern Languages Association, Rand Afrikaans University, Johannesburg, South Africa.

Appel, R. and P. Muysken. 1990. Language contact and bilingualism. London: Edward Arnold.

Baker, C. 1992. Attitudes and language. Clevedon: Multilingual Matters.

Blommaert, J., J. Collins and S. Slembrouck. 2005. Spaces of Multilingualism. Applied Linguistics 25(3): 197-216.

Blommaert, J., N. Muyllaert, M. Huysmans and C. Dyers. 2005. Peripheral normativity. The production of locality in a South African township school. Linguistics and Education 16: 378-403.

Combrink, J. 1978. Afrikaans: Its origin and development. In L. Lanham and K. Prinsloo (eds). Language and communication studies in South Africa: Current issues and directions in research enquiry. Cape Town: Oxford University Press. pp. 69-95.

Dyers, C. 2001. Language, identity and nationhood: Language use and attitudes among Xhosa students at the University of the Western Cape, South Africa. Doctoral dissertation, University of the Western Cape.

Dyers, C. 2004. Ten years of democracy: Attitudes and identity among some South African school children. Per Linguam 20(1): 22-35.

Dyers, C. 2008. Truncated multilingualism or language shift? An examination of language use in intimate domains in one South African township. Journal of Multilingual and Multicultural Development 29(2): 110-126.

De Klerk, V. 2000. To be Xhosa or not to be Xhosa - that is the question. Journal of Multilingual and Multicultural Development 21(3): 198-215.

Edwards, J. 1995. Multilingualism. London: Penguin.

Fasold, R. 1995. The sociolinguistics of society. Cambridge: Basil Blackwell.

Fishman, J. 1965.Who speaks what language to whom and when? La Linguistique 1965: 6768.

Fishman, J. (ed). 1968. Readings in the sociology of language. The Hague: Mouton.

Fishman, J. 1971. Advances in the sociology of language. The Hague: Mouton.

Fishman, J. 1972. The sociology of language. Rowley: Newbury House.

Havenga, W. 2006. Metropole East Education Provision Plan. Cape Town: Provincial Government of the Western Cape. 
Hendricks, F.S. 1996. Kaaps: Afwisseling met Engels is spontaan. Afrikaans Vandag, September 1996, pp. 8-9.

Joseph, J. 2006. Language and identity - National, ethnic, religious. Basingstoke: Palgrave MacMillan.

Kamwangamalu, N. 2003. Social change and language shift: South Africa. Annual Review of Applied Linguistics 23: 225-247.

Lanza, E. 2007. Multilingualism and the family. In P. Auer and L. Wei (eds). Handbook of multilingualism and multilingual communication. Berlin: Mouton de Gruyter. pp. 4568.

Malan, K. 1996. Cape Flats English. In V. De Klerk (ed). Varieties of English around the world: Focus on South Africa. Amsterdam: John Benjamins. pp. 125-148.

McCormick, K. 1989. Unfiltered talk: A challenge to categories. York Papers in Linguistics 13: 203-14.

McCormick, K. 1995. Code-switching, code-mixing and code convergence in Cape Town. In R. Mesthrie (ed.) Language and social history: Studies in South African sociolinguistics. Cape Town: David Phillip. pp. 193-208.

McCormick, K. 2000. Language in Cape Town's District Six. Oxford: Oxford University Press.

Mills, J. 2005. Connecting communities: Identity, language and diaspora. International Journal of Bilingual Education and Bilingualism 8(4): 253-274.

Moola, Z. 2002. A critical overview of the City of Cape Town's socio-economic policies with specific reference to the Wesbank area. Cape Town: Foundation for Contemporary Research.

Myers-Scotton, C. 2006. Multiple voices. Oxford: Blackwell.

Petersen, O., D. Isaacs H. Reisenhöfer. 1999. Joe Barber. Unpublished drama.

Petersen, O. and H. Reisenhöfer. 1999. Suip! Unpublished drama.

Ridge, S. 2000. Mixed motives: Ideological elements in the support for English in South Africa. In T. Ricento (ed). Ideology, politics and language policies: Focus on English. Amsterdam: John Benjamins. pp. 151-172.

Ridge, S. 2004. Language planning in a rapidly changing multilingual society. The case of English in South Africa. Language Problems and Language Planning 28(2): 199-215. 
Roberge, P. 1995. The formation of Afrikaans. In R. Mesthrie (ed). Language and social history: Studies in South African sociolinguistics. Cape Town: David Phillip. pp. 6888.

Schmidt, C. D. 2006. My church - my language? Language attitudes and language policy in a South African church. University of Leipzig Papers on Africa. Languages and Literatures 28.

Small, A. 1965. Kanna hy kô hystoe. Cape Town: Tafelberg.

South African Population Census 2001. Available at http://www.statssa.gov.za/census01/html /default.asp.

Soudien, C. 2007. Double discrimination in South African schooling. Paper presented at the WCCES XIII World Congress, Sarajevo, Bosnia.

Stone, G. 1995. The lexicon and sociolinguistic codes of the working-class Afrikaansspeaking Cape Peninsula coloured community. In R. Mesthrie (ed). Language and social history: Studies in South African sociolinguistics. Cape Town: David Phillip. pp. 277-290.

Tabouret-Keller, A. 1998. Language and identity. In F. Coulmas (ed). The handbook of sociolinguistics. Oxford: Blackwell. pp. 315-326.

Titus, D. 2008. Afrikaans en die kultuurlewe. Talk presented at the launch of the Afrikaanse Taalraad, Wellington.

Taylor, S. 2007. Education, inequality and economic development in South Africa. Paper presented at the WCCES XIII World Congress. Sarajevo, Bosnia.

Thim-Mabrey, C. 2003. Sprachidentität - Identität durch Sprache - Ein Problemaufriss aus sprachwissenschaftlicher Sicht. In N. Janich and C. Thim-Mabrey (eds). Sprachidentität - Identität durch Sprache. Tübingen: Gunter Narr Verlag. pp.1-18.

Triandis, H. 1971. Attitude and attitude change. New York: John Wiley and Sons.

Warner, F. 2008. Exploring language shift in a Western Cape "Coloured" community. Paper presented at the $3^{\text {rd }}$ International Symposium on Intercultural Communication and Pragmatics. Stellenbosch, South Africa.

Webb, V. 1989. Die Afrikaanse variasietaalkunde. In T.J.R. Botha (ed). Inleiding tot die Afrikaanse Taalkunde. $2^{\text {nd }}$ edition. Pretoria: Academica. pp. 412-435.

Webb, V. 1999. Multilingualism in democratic South Africa: The over-estimation of language policy. In L. Limage (ed). Comparative perspectives on language and literacy: Selected papers from the work of the Language and Literacy Commission of the $10^{\text {th }}$ 
72 Charlyn Dyers

World Congress of Comparative Education Societies. Dakar: UNESCO-BREDA. pp. 65-86.

Webb, V. 2002. Language in South Africa: The role of language in national transformation, reconstruction and development. Amsterdam/Philadelphia: John Benjamins. 